\title{
ARCHITECTURE AS IDENTIFICATION OF PLACE: THE CASE OF JOGLO KAMPUNG KETANDAN SURABAYA
}

\author{
Andy Mappajaya*, Nur Endah Nuffida*, Murni Rachmawati* \\ *) Department of Architecture, Institute of Technology Sepuluh Nopember, \\ Indonesia \\ e-mail: mappajaya@arch.its.ac.id
}

\begin{abstract}
To make a site become a place is the existential function of architecture. The definition of architecture as identification of place (Unwin, 2003), comes with a purpose that architecture is also a process to discover the essence, the meaning conceivably present in the given environment. In the case of Kampung Ketandan Surabaya, the architecture is produced by the community by preserving and revitalizing the character of the kampung, with regards to its history, its activities and its buildings. Balai Pertemuan Warga in the form of Pendhopo is one of many other community centers in the kampung. This paper investigates in what way architecture generates symbolic places. Descriptive criticism is used as a method to investigate the phenomenon by considering architecture as a way of art and finding the interrelationship between the elements in it. To grasp the context of Kampung Ketandan, a case study method is chosen because of its ability to explore and endow the holistic, yet meaningful aspects of a presence phenomenon happening in reallife. The results of the study revealed that place is a holistic phenomenon, determining an 'environmental character' and architecture is a symbol to identify it.
\end{abstract}

Keywords: architecture, identification of place, Pendhopo Kampung Ketandan

\section{INTRODUCTION}

This paper begins with questioning what is 'place' meaning for architecture. The aim here is to unfold the usefulness of identifying places by architectural meaning.

The name Ketandan was first written as Ketandang on a 1270 map (Sulistyowati et.al, 2016). It was a freshwater swamp located on the north side of an enclosed area or a shelter. In 1787, a track began to emerge, particularly what is now Jalan Tunjungan, but no housing settlement was in sight. Housings were sprouting around Prabang and Gentengkali. In the first quarter of the $19^{\text {th }}$ century, spatial planning showed Jalan Tunjungan and Embong Malang. Kebangsaan, written as Kebangserin, was depicted with tree symbols. In an 1866 map, Kebangsren, Ketandan, and a part of Embong Malang were swamped by Chinese cemeteries (Bong). Aside from 
Bongs in Banyuurip and Pasar Bong in Kembang Jepun, the Bong in Ketandan and Kebangsren was one of the largest in Surabaya.

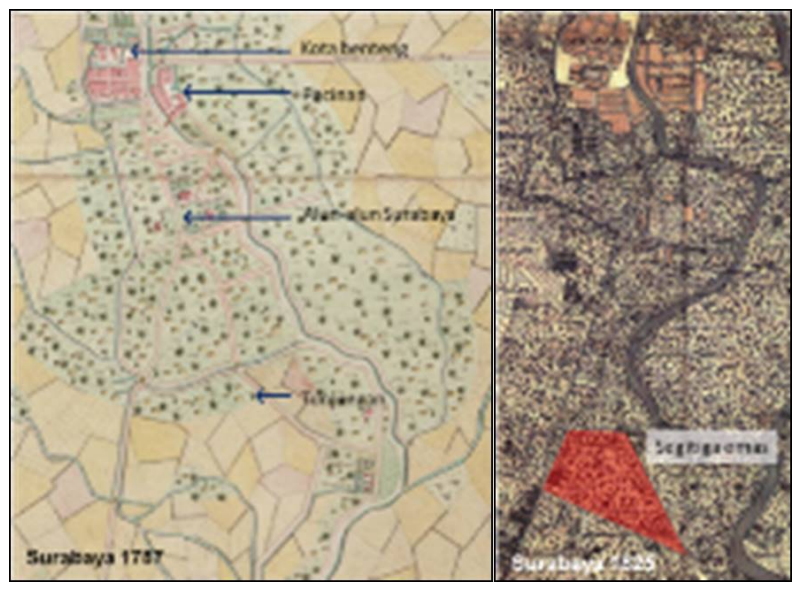

Figure 1. Surabaya development in the $18^{\text {th }}$ (left) and $19^{\text {th }}$ century (right) Source: Sulistyowati, M. et.al., 2016

The postal roadway plan initiated by H. W. Daendels who was the GovernorGeneral of Dutch East Indies has greatly affected the Jalan Tunjungan corridor, from Jembatan Merah through Tunjungan towards Jalan Basuki Rahmat and further south. This road plan triggered the birth of a new area of service trade and housings on the backside. Tunjungan corridor that was once a quiet countryside has evolved into a modern trade center. This certainly encouraged people to strategically build housings nearby. As of the 1930s, many Bongs were found in Kebangsren and Ketandan. According to the Dutch newspaper De Indische Courant dated March $7^{\text {th }}$, 1935, however, many Bongs were dug up and replaced with housings. Residents even utilized tombs for different purposes.

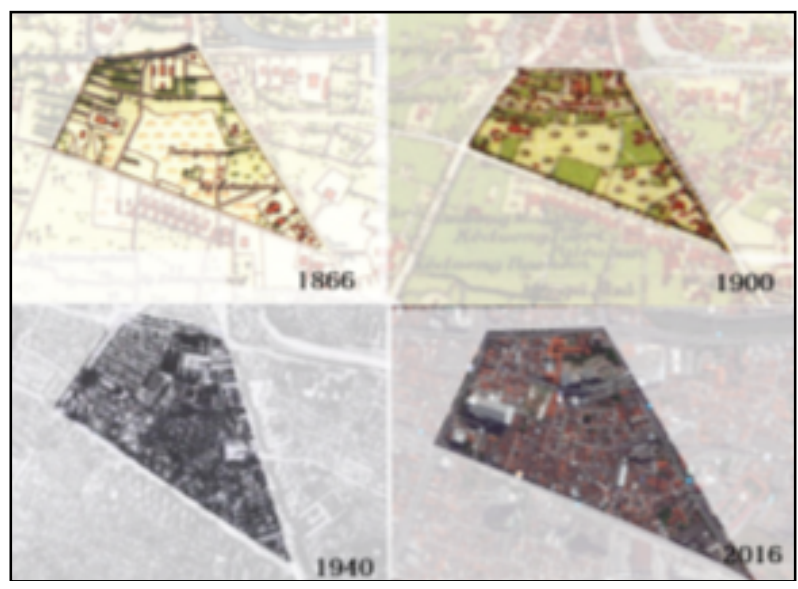

Figure 2. Surabaya development in the $18^{\text {th }}$ (left) and $19^{\text {th }}$ century (right) Source: Sulistyowati, M. et. al, 2016 
Amidst the development of Bong complexes into housings, the same newspaper dated May $27^{\text {th }}, 1935$, highlighted Kampung Ketandan as a unique place of serenity in a hectic city. It is suggested here that the serene atmosphere of Kampung Ketandan and Kebangsren has not changed over the years.

One of the characteristics of the kampung is a neighborhood of alleys which are parts of residents' yards. It means the alleys serve as a social space as well as an economic space for residents. The potential of public space in Kampung Ketandan and Kebangsren includes:

1. Neighborhood alleys are well-managed and green

2. The communal area in front of Mbah Tondo's tomb (Balai Budaya) is frequented by children and elderlies to take a break. Public events are frequently held there as well

3. A badminton field in Kampung Kebangsren marks a wide-open space for public gathering, which provides breathing space in a kampung.

Open space is an important element of a kampung. In a jungle of concrete and steel, a kampung usually means a crowded slum with limited space. Kampung Ketandan is a kampung with sufficient open spaces. In addition to alleys and front porches, the kampung also has communal open spaces for public activities.

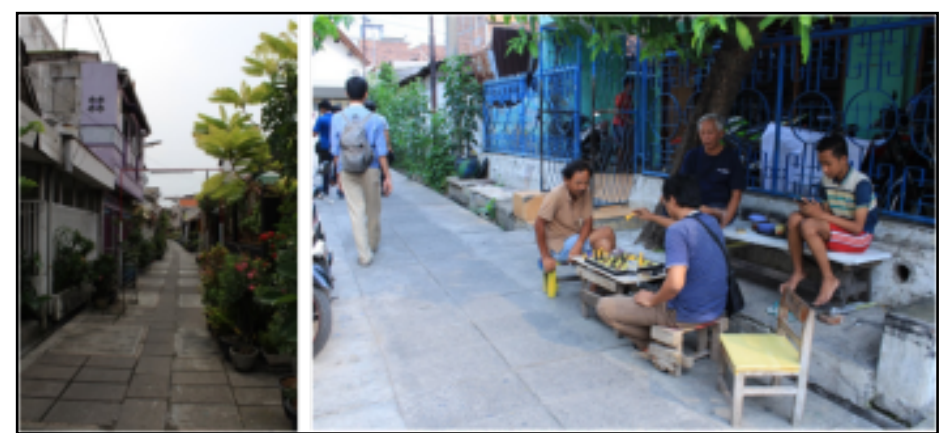

Figure 3. Alleys as open spaces in Kampung Ketandan Source: Sulistyowati, M. et. al, 2016
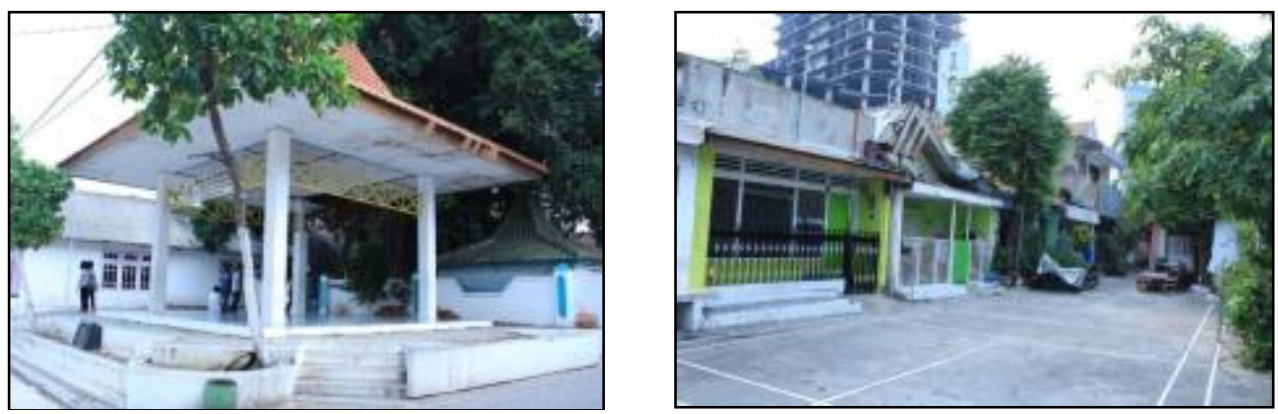

Figure 4. Communal open spaces Source: Sulistyowati, M. et. al, 2016 
Open spaces in Kampung Ketandan are well-managed, clean, and green as shown in figures above. Residents socialize by playing chess and other activities. What is not found there is unison in design ideas and open space optimization to enhance their functionalities for kampung residents.

The main idea of kampung open space is flexibility, which means flexible open spaces in terms of functionality, utilization, and users. Spatial flexibility refers to a constrained space that is conditioned to harbor different activities without altering its existing features. Not only the design is flexible, but it is also intended to encourage the community to conduct common activities inside or around the open space. Open spaces are created as a place for common activities and as a trigger for other activities. Open spaces can be utilized for formal activities of the residents such as routine activities (meetings, arisan, etc.) and for children to practice art performances. The same spaces cater to informal activities, including children playing games and sports, studying, even for mothers to conduct simple economic activities of opening food stalls (under certain conditions, i.e.: cleanliness, etc.).

In accordance with the primary idea of flexibility as the kampung open space concept, the cultural hall of Kampung Ketandan can be utilized for multiple purposes, including as a studio for practicing Surabaya traditional arts (i.e.: Remo dance or Parikan Suroboyo), and as a temporary commercial area of food stalls. Hence, it could cater to visitors who want to taste traditional Surabaya foods.

\section{THEORY / RESEARCH METHODS}

Architecture is operated by and for people (Unwin, 2003), by organizing the world around them into places which they use for a variety of purposes. Architecture, then, operates as identification of place. Furthermore, place signifies context. It can be said that as meaning is to language, likewise place is to architecture. Architecture gives the place a significance, its meaning.

As the identification of place, architecture affirms the essential part played in architecture not only by the designer but also the user; and for the designer, it avers the places proposed should accord with places used, even if it takes time for this to happen. The theoretical view put forth by Unwin underlines the importance of comprehension of the world views of communities. Architecture, as a presentation of a worldview, varies at many levels: personal, socio-cultural, and between different sub-cultures within a society.

At a socio-cultural level, communities in the urban kampung, concerning their world-views as local wisdom are highly considered (Muwifanindhita dan Idajati, 2018). Research done by Wahid \& Widyawati (2018) at Kampung Lengkong Ulama, at Tangerang Selatan, shows that the strong value of traditions existing in the kampung is what makes their identity stronger. Strong values of traditions in a kampung are underlined by this research as triggered by notable places, through generations, such as mosque and tomb, which generate a place of identity in the kampung. 


\section{RESULTS AND DISCUSSION}

The theoretical framework embraces three postulates used in this research :

1. Architecture as Identification of Place

2. The strong value of traditions in the form of architecture

3. Architecture as a given meaning to the context of place

Communal space in the form of Pendhopo is located in front of the tomb of Mbah Tondo as a stage for various public performances. Pendhopo is a pavilion-like structure that stands in front of a Javanese house compound (Kusno, 2010). It is noticeable from the street and accessible to people. Standing in front of the ruler's house, the pendhopo is the symbol of mediating of the ruler and the ruled, the inner and outer circle, thus symbolizing a pattern of communication. This definition is analyzed further by the case of the Joglo of Kampung Ketandan

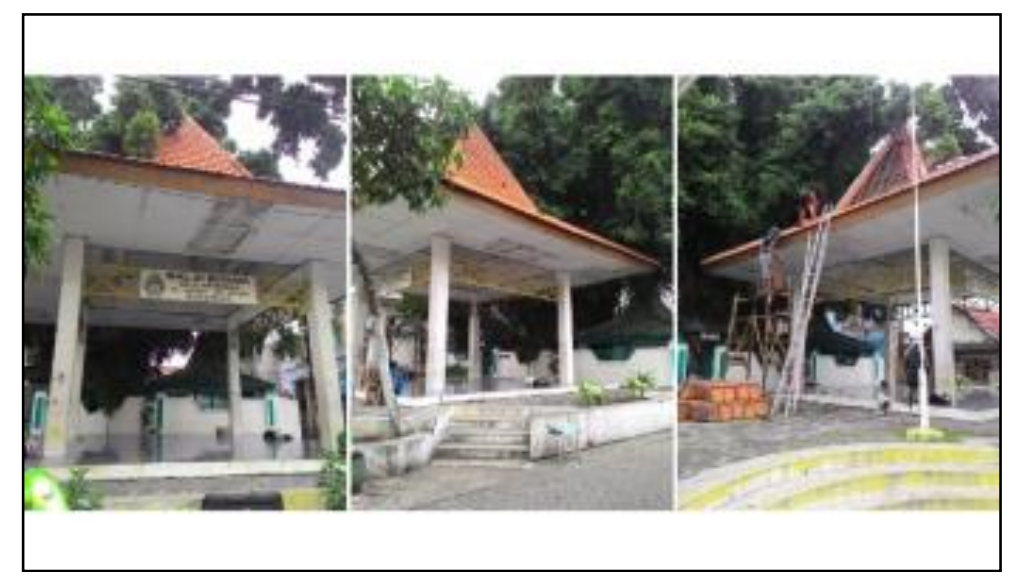

Figure 5. Joglo as a Communal Open Space (before renovations) Source: Personal Documentation, 2016

The Pendhopo has been renovated and remodeled with greeneries by people of Kampung Ketandan. The old Pendhopo which the communities called Joglo which was made of bricks and stones were replaced by the new one made of wood.

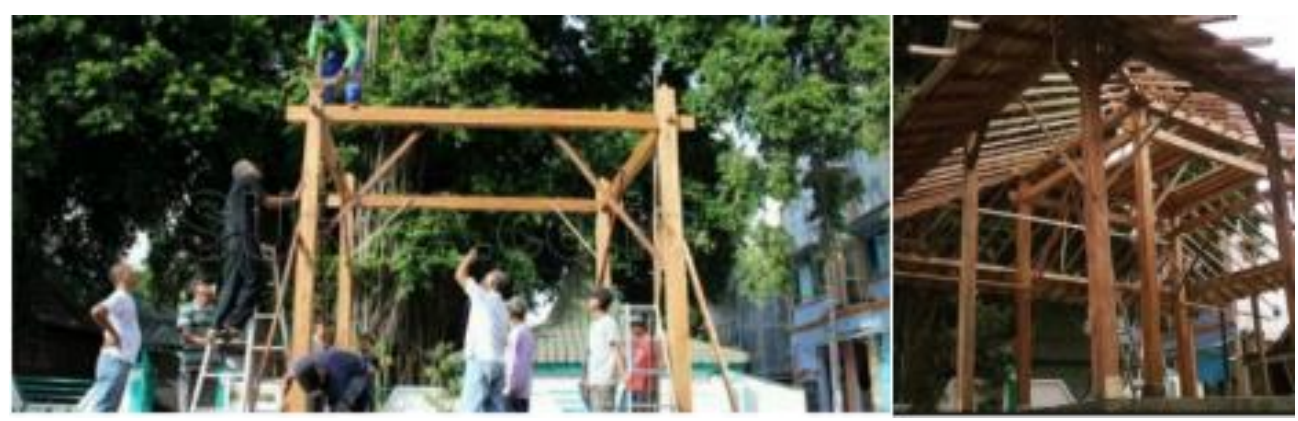

Figure 6. The Joglo Assembling Process (renovations, wood materials) Source: Personal Documentation, 2016. 


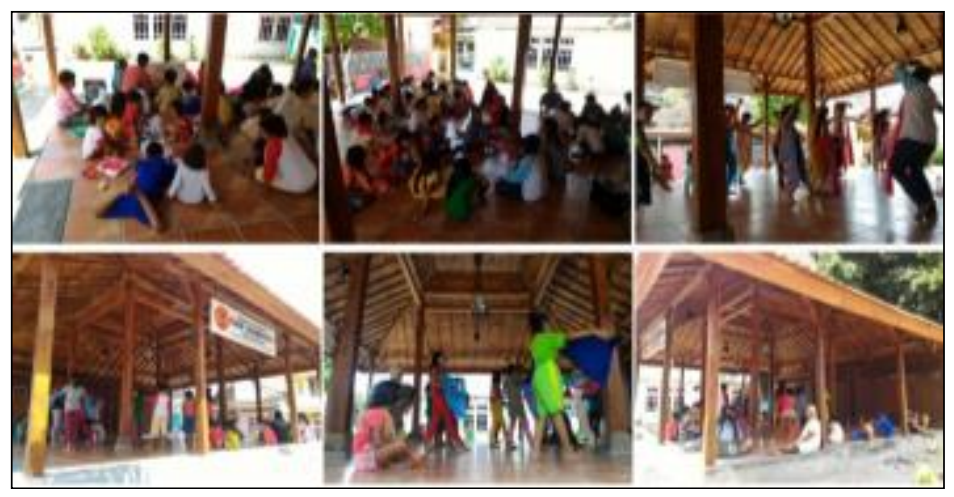

Figure 7. The communal activities at Joglo Kampung Ketandan (after renovations) Source: Personal Documentation, 2016.

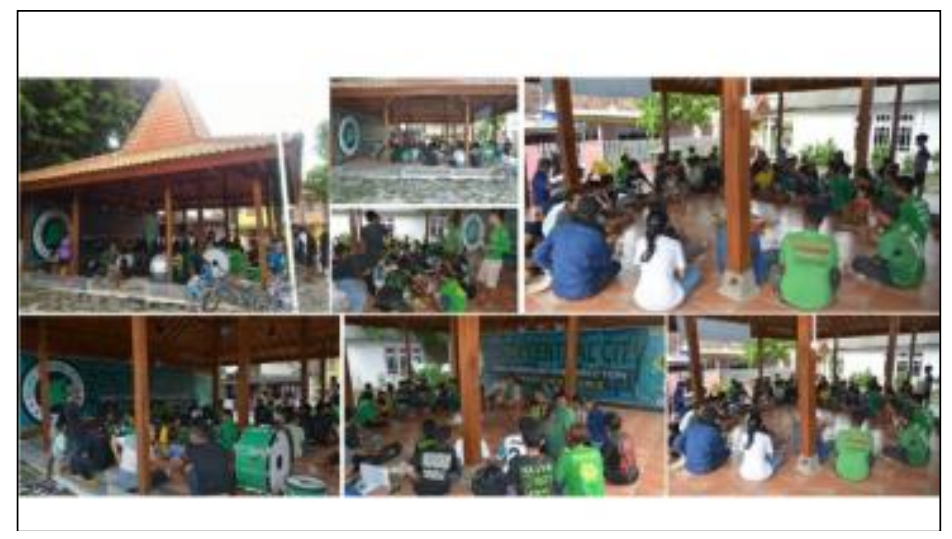

Figure 8. Joglo Kampung Ketandan as a place for gathering for Surabaya's communities Source: Personal Documentation, 2017

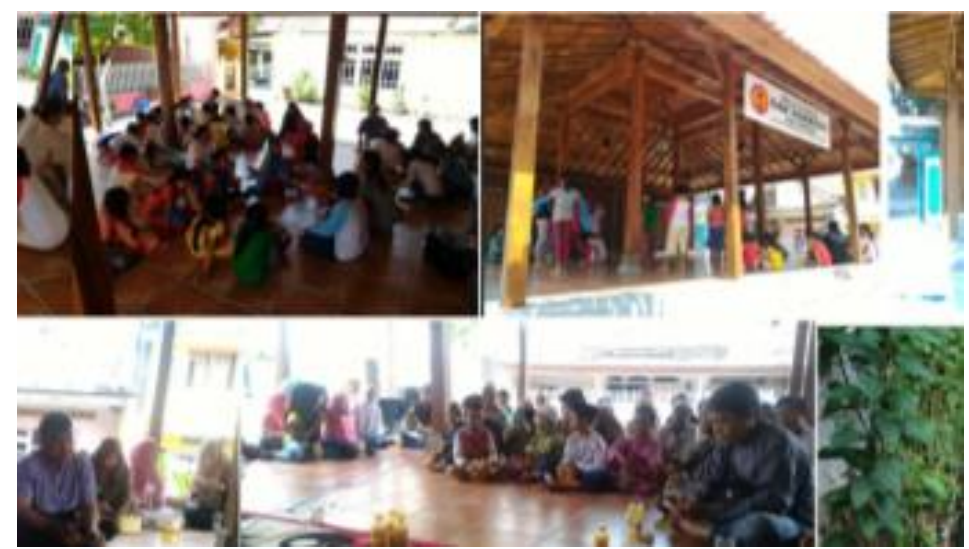

Figure 9. Joglo Kampung Ketandan as a place for gathering for international communities and triggering social space for the kampung's citizens Source: Personal Documentation, 2018 
Joglo Kampung Ketandan, after the renovations, became a social place, one of the centers of communal activities, not only for the Kampung Ketandan Communities but also for Surabaya's citizens. The Joglo that is used as a center for Ketandan's local community activities proved to be a convenient place that attracts tourists to come (Muwifanindhita and Idajati, 2018). The previous research by Mufiwanindhita and Idajati (2018) showed that infrastructure, like Joglo Kampung Ketandan and electricity, was one of the most influential factors that triggered a lot of activities in the kampung. People gathered more often and it brings a lively atmosphere at Kampung Ketandan. The research also found the appreciation and support from the Surabaya government brought people to participate more in activities of Kampung Wisata Ketandan (Ketandan Tourist Village). Kampung Ketandan as a destination of tourism in Surabaya is supported by Surabaya's Government as one of the municipality's programs

\section{CONCLUSIONS}

The results of the study revealed that Joglo Kampung Ketandhan is an architectural element that defines a place for its communities. As a holistic phenomenon, 'environmental character' is shown by activities done in the Joglo and its surroundings. Architecture is a symbol to identify the value of communities. Architecture is, before all else, identification of place. To think architecture as this kind of identification, activities that characterize architecture are on solid ground. The experience of place needs further study, as a further definition in the study of atmospheric architecture as also part of the identification of place. Architecture and its meaning could drive the experience of place to define things that one considers important for people in daily lives: a leveled area from the ground as a place of ceremonies and performance, a 'transparent' wall as a flexible territory and free access and a roof as a shelter and shade. Those three elements are defined in the system of tectonics at Joglo Kampung Ketandan and also symbolize values of the communities there: honesty, respect, and hospitality. Through architecture, those values are cohesively arranged in a spatial order and bring new meaning to the communities.

\section{REFERENCES}

De Souza, R. C. F. (2015) Case Studies as Method for Architectural Research, $<$ https://www.researchgate.net/publication/314147521_Case_Stud ies_as_method_for_architectural_research > (Accessed on 19 August 2019).

Kusno, A. (2010) The Appearances of Memory, Mnemonic Practices of Architecture and Urban Form in Indonesia (Asia-Pacific, Culture, Politics, and Society) Durham, North Carolina, United States, Duke University Press Books.

Monnet, J. (2011) Translated by Angela Verdier. The Symbolism of Place: a Geography of Relationships between Space, Power, and Identity< https://journals.openedition.org/cybergeo/24747?lang $=e n>$ (Accessed on 20 August 2019)

Muri, Y. (2014) Metode Penelitian, Jakarta, Prenada Media. 
Muwifanindhita, M. B. and Idajati, H. (2018) Identifikasi Faktor yang Memengaruhi Partisipasi Masyarakat Kampung Ketandan sebagai Kampung Wisata di Surabaya, Jurnal Teknik ITS Vol. 7, No. 2, ISSN: 2337-3539 (2301-9271 Print)

Sulistyowati, M. et.al. (2016) Rencana Penataan Kampung Wisata Kampung Ketandan dan Kebangsren. Surabaya, Laboratorium Perkembangan Arsitektur ITS.

Unwin, S. (2003). Analyzing Architecture, London, Routledge.

Wahid, A. G. A. and Widyawati (2018) Sociocultural Landscape of Rural Community in New Town Development of Bumi Serpong Damai City Kota Tangerang Selatan, Indonesia. PEOPLE, International Journal of Social Sciences, Vol.4, No.3, 164-180. 